\title{
EVALUASI ARBORETUM SYLVA INDONESIA PC UNTAN DAN PENDOPO GUBERNUR KALIMANTAN BARAT MENJADI HUTAN KOTA DI PONTIANAK KOTA
}

\author{
(Evaluation Arboretum Sylva Indonesia PC UNTAN and West Borneo Guverno's Pavilion \\ becomingUrban Forest in Pontianak City)
}

\author{
Putri Nurul Oktebriyani, Iswan Dewantara, Erianto \\ Fakultas Kehutanan Universitas Tanjungpura, Jalan Imam Bonjol Pontianak, 78124 \\ Email: nurulputri796@gmail.com
}

\begin{abstract}
Evaluation of urban forest trees species is carried out with the aim the types of trees species that have been planted as an appropriate type in accordance with the functions and supporting development of urban forests. Supporting management urban forests in the future, spatial data of trees species is needed. This study aims to (1) to obtain the types and trees compiler in urban forest (2) to evaluation the suitability of treescompiler in urban forests (3) to determine the position of existing trees species in urban forests. This study used survey and identification method to determine the types of urban forest and the existing trees species. Assessment the suitability of tree species is based on the place of growth and literature study. Data analysis is conducted by considering silvicultural, management and aesthetic requirements. Based on this criteria are made that is appropriate, quite appropriate and not appropriate. The results showed that trees species compiler in Arboretum there are 35species of tree and in the West Borneo Governor's Pavilionthere are17species of tree that have appropriate criteria, there are 3 tree species that have quite approriate based on silvicultural, management and aesthetic requirements.
\end{abstract}

Keyword : evaluation, tree, urban forest

\section{PENDAHULUAN}

Keterdapatan Ruang Terbuka Hijau memberikan hal positif terhadap lingungan sekitar wilayah perkotaan. Kemajuan pembangunan dan kepadatan penduduk serta bertambahnya jumlah kendaraan menyebabkan menurunnya kualitas lingkungan wilayah perkotaan.Kondisi ini akan semakinburuk apabila pemerintah daerah tidakmempersiapkan strategi perencanaan khusus untukmengantisipasi segala bentuk perubahan yangterjadi, khususnya terhadap pengelolaan lingkunganhidup kawasan perkotaan secara berkesinambungan.

Arboretum Sylva Indonesia PC UNTAN dan Pendopo Gubernur Kalimantan Barat merupakan RTH yang didominasi oleh pepohonan dan lokasinya tepat berada di tengah kota. Dua hutan Ruang Terbuka Hijau (RTH) memiliki peran yang sangat penting bagi kualitas lingkungan hidup yang ada khususnya di tengah kota Pontianak. Salah satu langkah yang dapat diambil untuk menjaga lingkungan yang ada di Pontianak adalah dengan merubah status kawasan tersebut menjadi Hutan Kota. Cara yang dapat dilakukan untuk 
meningkatkan statusnya ialah dengan mengevaluasi jenis pohon penyusun yang ada di lokasi tersebut.

Pemilihan jenis pohon penyusun Hutan Kota di Pontianak Kota perlu diperhatikan oleh pemerintah. Jenis pohon apa saja yang dapat ditanam untuk dijadikan penyusun hutan kota yang memiliki nilai silvikultur, manajemen dan estetika dengan jenis pohon yang mengurangi polutan dan kebisingan di lingkungan kota khususnya di Pontianak kota.Pengambilan titik koordinat dilakukan juga untuk mengetahui posisi setiap jenis yang ada dan sebagai data spasial terhadap jenis yang telah di lakukan evaluasi penilaian. Data spasial pohon penyusun hutan kota ini nantinya diperlukan sebagai data base pengawasan bagi pengelolaan hutan kota.

Tujuan penelitian ini adalah untuk mendapatkan tipe hutan kota serta jenis penyusunnya, mengevaluasi kesesuaian jenis pohon penyusunnya dan menentukan posisi setiap jenis pohon penyusun hutan kota di Pontianak Kota. Penelitian ini diharapkan dapat menjadikan Arboretum Sylva Indonesia PC UNTAN dan Pendopo Gubernur Kalimantan Barat sebagai hutan kota di kota Pontianak. Disamping itu, data spasial akan lebih membantu dalam pengelolaan hutan kota kedepannya.

\section{METODE PENELITIAN}

Penelitian ini dilaksanakan di Arboretum Sylva Indonesia PC. UNTAN dan Pendopo Gubernur Kalimantan Barat. Objek penelitian ini adalah tumbuhan pada tingkatan pohon yang memiliki $\mathrm{DBH} \geq 20 \mathrm{~cm}$. Alat dan bahan yang digunakan adalah : peta administrasi kota Pontianak, tallysheet, GPS, kamera, buku kunci identifikasi pohon. Penelitian ini menggunakan metode survey lapangan untuk mengetahui jenis pohon penyusun hutan kota pada setiap lokasi. Pengambilan data dilakukan secara sensus pada setiap tumbuhan dengan tingkatan pohon. Hasil identifikasi jenis pohon digunakan untuk evaluasi kecocokan jenis pohon penyusun hutan kota. Studi pustaka dilakukan untuk mengetahui persyaratan tumbuh dan karakteristik jenis-jenis pohon hutan kota di lokasi penelitian. Analisis kecocokan jenis pohon penyusun hutan kota dilakukan dengan pengolahan data dan tabulasi, kemudian dianalisis secara desktiptif (Indriyanto 2006).

Komponen penentuan skor berdasarkan Indriyanto (2006) dan Saebo et al (2005). sebagai berikut :

\section{Persyaratan Silvikultur}

Guna memenuhi fungsi hutan kota secara optimal, maka jenis pohon hutan kota harus memenuhi persyaratan silvikultural, diantaranya adalah berada pada tempat tumbuh yang sesuai dengan kebutuhan pertumbuhannya (kondisi iklim dan edafis), dapat tumbuh pada tanah yang miskin hara, mampu memulihkan kesuburan tanah, tahan terhadap serangan hama dan penyakit, spesies tumbuhan yang selalu hijau, batang pohon dan cabang kuat sehingga tidak mudah patah dan tumbang, akar tidak merusak jalan, beton, dan 
bangunan yang ada disekitarnya (Indriyanto 2006). Jenis pohon untuk hutan kota harus toleran terhadap suhu tinggi dan penyinaran matahari yang

Tabel 1. Komponen, kriteria dan skor untuk pemenuhan persyaratan silvikultural dalam pemilihan jenis pohon hutan kota (Component, criteria and score based on silviculture requirements for urban forest trees species selecting)

\begin{tabular}{|c|c|c|}
\hline Komponen & Kriteria & Skor \\
\hline \multirow[t]{2}{*}{ Ketinggian tempat } & $0-500 \mathrm{mdpl}$ & 2 \\
\hline & $>500 \mathrm{~m} \mathrm{dpl}$ & 1 \\
\hline \multirow[t]{2}{*}{ Curah hujan } & $1.200-2.000 \mathrm{~mm} / \mathrm{th}$ & 2 \\
\hline & $<1.200$ dan $>2.000 \mathrm{~mm} / \mathrm{th}$ & 1 \\
\hline \multirow{2}{*}{$\begin{array}{l}\text { Toleran terhadap tanah miskin } \\
\text { hara }\end{array}$} & Toleran & 2 \\
\hline & Tidak toleran & 1 \\
\hline \multirow{2}{*}{$\begin{array}{l}\text { Sifat memulihkan kesuburan } \\
\text { tanah }\end{array}$} & Mampu menyuburkan tanah & 2 \\
\hline & Tidak mampu menyuburkan tanah & 1 \\
\hline \multirow[t]{2}{*}{ Sifat menggugurkan daun } & Selalu hijau (evergreen) & 2 \\
\hline & Menggugurkan daun & 1 \\
\hline \multirow[t]{2}{*}{ Tahan hama dan penyakit } & Tahan & 2 \\
\hline & Tidak Tahan & 1 \\
\hline \multirow{2}{*}{$\begin{array}{l}\text { Ketahanan batang pokok dan } \\
\text { percabangan terhadap angin }\end{array}$} & Tidak mudah tumbang dan patah & 2 \\
\hline & Mudah tumbang dan patah & 1 \\
\hline \multirow{2}{*}{$\begin{array}{l}\text { Kondisi perakaran terhadap } \\
\text { bangunan sekitarnya }\end{array}$} & Tidak merusak/menganggu & 2 \\
\hline & Merusak/menganggu & 1 \\
\hline \multirow[t]{2}{*}{ Toleransi terhadap suhu tinggi } & Toleran & 2 \\
\hline & Tidak Toleran & 1 \\
\hline \multirow{2}{*}{$\begin{array}{l}\text { Toleransi terhadap penyinaran } \\
\text { matahari yang kuat }\end{array}$} & Toleran & 2 \\
\hline & Tidak toleran & 1 \\
\hline \multirow[t]{2}{*}{ Toleran terhadap kekurangan air } & Toleran & 2 \\
\hline & Tidak Toleran & 1 \\
\hline
\end{tabular}

Sumber;Saebo et al. (2005) dan Indriyanto(2006)

\section{Persyaratan Manajemen}

Cara penanaman spesies tumbuhan yang dipilih harus mudah, pemeliharaannya mudah dan murah, pengamanan dan pemanfaatannya mudah (Indrianto, 2006). Jenis pohon yang dipilih untuk pengembangan hutan kota harus memiliki fungsi yang diharapkan sesuai dengan tujuan pembangunan hutan kota, yaitu bertajuk kuat serta toleran terhadap kekurangan air (Saebo et al. 2005). Komponen untuk pemenuhan persyaratan silvikultural disajikan pada Tabel 1. 
Tabel 2. Komponen, kriteria dan skor untuk pemenuhan persyaratan manajemen dalam pemilihan jenis pohon hutan kota(Component, criteria and score based on management requirements for urban forest trees species selecting)

\begin{tabular}{|c|c|c|}
\hline Komponen & Kriteria & Skor \\
\hline 1 & 2 & 3 \\
\hline \multirow{2}{*}{ Cara penanaman } & Mudah & 2 \\
\hline & Sulit & 1 \\
\hline \multirow[t]{2}{*}{ Cara pemeliharaan } & Mudah dan murah & 2 \\
\hline & Tidak mudah dan mahal & 1 \\
\hline \multirow{2}{*}{ Cara pengamanannya } & Mudah & 2 \\
\hline & Tidak Mudah & 1 \\
\hline 1 & 2 & 3 \\
\hline \multirow{2}{*}{ Cara pemanfaatannya } & Mudah & 2 \\
\hline & Tidak mudah & 1 \\
\hline \multirow{2}{*}{$\begin{array}{l}\text { Fungsi tajuk sebagai peneduh (tebal dan } \\
\text { rapat) }\end{array}$} & Baik sebagai peneduh (tajuk tebal dan rapat & 2 \\
\hline & $\begin{array}{l}\text { Kurang baik sebagai peneduh (tajuk tipis } \\
\text { dan ringan) }\end{array}$ & 1 \\
\hline \multirow[t]{2}{*}{$\begin{array}{l}\text { Fungsi tajuk sebagai pelindung angin } \\
\text { (kuat dan rapat) }\end{array}$} & $\begin{array}{l}\text { Baik sebagai pelindung angin (tajuk kuat } \\
\text { dan rapat) }\end{array}$ & 2 \\
\hline & $\begin{array}{l}\text { Kurang baik sebagai pelindung angin (tajuk } \\
\text { tidak kuat dan ringan) }\end{array}$ & 1 \\
\hline \multirow{2}{*}{$\begin{array}{l}\text { Kemampuan dalam pengurangan } \\
\text { pencemaran }\end{array}$} & Tinggi & 2 \\
\hline & Rendah & 1 \\
\hline
\end{tabular}

Sumber ;Saebo et al. (2005) dan Indriyanto(2006)

\section{Persyaratan estetika}

Jenis pohon yang akan ditanam pada hutan kota harus memiliki habitus yang menampakkan kesesuaian dengan tujuan keindahan (Indriyanto 2006). Jenis pohon yang dipilih dalam pengembangan hutan kota selain fungsi estetika/keindahan harus mendukung fungsi pendidikan/edukasi dan kesehatan serta kenyamanan masyarakat di sekitarnya, diantaranya adalah :

a. Memiliki tajuk, percabangan, daun /atau bunga yang indah sehingga berfungsi sebagai penambah estetika atau keindahan lingkungan perkotaan, b. Memiliki fungsi sebagai sarana pendidikan,

c. Memiliki buah berukuran relatif kecil sehingga ketika jatuh tidak membahayakn manusia atau merusak fasilitas/banguunan di sekitarnya,

d. Tidak menghasilkan getah yang beracun ata berbahaya bagi makhluk hidup,

e. Tidak menghasilkan serbuk sari yang berpotensi menimbulkan alergi bagi manusia.Komponen skor untuk pemenuhan persyaratan estetika disajikan pada Tabel 3 . 
Tabel 3. Komponen, kriteria dan skor untuk pemenuhan persyaratan estetika dalam pemilihan jenis pohon hutan kotaComponent, criteria and score based on aesthetic requirements for urban forest trees species selecting)

\begin{tabular}{lllc}
\hline \multicolumn{1}{c}{ Komponen } & \multicolumn{1}{c}{ Kriteria } & Skor \\
\hline Habitus (tajuk, percabangan, & daun & Indah & $\mathbf{2}$ \\
dan/atau bunga) & Tidak Indah & 2 \\
Fungsi sebagai sarana pendidikan & Ya & 1 \\
& Tidak & 2 \\
Ukuran Buah & Buah berukuran relatif kecil & 1 \\
& Buah berukuran besar & 2 \\
Getah beracun/berbahaya & Tidak menghasilkan getah & 1 \\
& beracun/berbahaya & 2 \\
Potensi alergi dari serbuk sari & Menghasilkan getah beracun/berbahaya & 1 \\
& Tidak berpotensi alergi & 2 \\
& Berpotensi alergi & 1 \\
\hline
\end{tabular}

Sumber ;Saebo et al. (2005) dan Indriyanto(2006)

Memenuhi kriteria kesesuaian

dilakukan penghitungan terhadap skor setiap jenis pohon diperoleh dari hasil survei lapangan. setelah data didapatkan, setiap jenis pohon diurutkan berdasarkan skor tertinggi sampai dengan terendah lalu dikelompokkan menjadi tiga kelas kriteria kesesuaian sebagai berikut :

Kriteria kesesuaian :

a. Tidak sesuai (skor 23-30,33)

b. Cukup sesuai (skor $>30,33-38,33$ )

c. Sesuai (skor 38,33-46)

Guna mengetahui jenis-jenis pohon yang sesuai dengan kondisi persyaratan tumbuh dan toleran terhadap pencemaran udara dilakukan dengan studi pustaka. Jenis pohon yang dianggap sesuai dalam pengembangan hutan kota adalah jenis pohon yan memiliki kemampuan tinggi dalam penyerapan polutan dan memiliki daya tahan tinggi (toleran) terhadap paparan polutan di lokasi penelitian.

Pemilihan jenis pohon penyusun hutan kota yang tepat hara mempertimbangkan faktor tempat tumbuh, faktor ekonomi dan faktor sosial (Miller 1997). Pemilihan jenis pohon pada setiap tipe hutan bervariasi mengingat tujuan pengembangan hutan kota pada setiap tipe hutan kota juga beragam.

Pengambilan titik koordinat setiap individu jenis pohon kemudian dilakukan pengolahan menggunakan Software Arc.GIS 10.3 yang hasilnya berupa peta penyebaran pohon di lokasi hutan kota. Peta penyebaran memberikan infomasi berupa titik dari pohon yang telah dilakukan penilaian dengan persyaratan silvikultur, manajemen, dan estetika menghasilkan tiga kriteria kelas sesuai,cukup sesuai dan tidak sesuai dengan memberikan simbol dan warna yang berbeda-beda disetiap kriteria kelas.

HASIL DAN PEMBAHASAN

Tipe Hutan Kota dan Jenis

Penyusunnya

\section{Arboretum Sylva Indonesia PC UNTAN}

Berdasarkan identifikasi tipe hutan kota di lokasi penelitian, Arboretum 
merupakan tipe hutan kota berupa pelestarian plasma nutfah dan rekreasi. Arboretum Sylva Indonesia PC. UNTAN sebagai konservasi plasma nutfah khususnya vegetasi secara in situ dan ex situ, karakteristik nya ialah pepohonan yang unik, langka dan atau unggulan Kalimantan Barat. Hutan Kota Arboretum Sylva Indonesia PC. UNTAN dikelola dengan maksud sebagai pengoleksian, perlindungan dan pelestarian flora dan fauna Kalimantan Barat dan juga dengan tujuan sebagai tempat pengembangan keanekaragaman hayati, tempat pengembangan pendidikan, pengembangan hutan kota serta sarana rekreasi dan hiburan bagi masyarakat. Kawasan hutan kota ini juga dipergunakan sebagai tempat photography dan film, jogging dan cycling, ekowisata dan outbond. Hutan Kota Arboretum Sylva Indonesia PC UNTAN merupakan hutan bersrata banyak, yaitu terdiri dari pepohonan yang membentuk tajuk tinggi, semak belukar, liana, epifit, tanaman merambat lain dan penutup tanah atau rerumputan. Berdasarkan hasil penelitian Arboretum Sylva Indonesia PC UNTAN memiliki jenis pohon penyusun sebanyak 38 jenis pohon. Dilihat dari Tabel 5, jenis pohon penyusun hutan kota di Arboretum Sylva Indonesia PC UNTAN tergolong dalam 19 famili. Jenis pohon di Arboretum merupakan jenis pohon yang ekstotik dan endemik Kalimantan yang ditanam seperti Tengkawang (Shorea stenoptera), Kawi (Shorea balangeran), Bengkirai (Shorea laevis), Gaharu (Aquilaria malaccensis), Shorea palembanica), (Shorea parvistipulata), (Shorea stenoptera), (Shorea leprosula), (Shorea fallax, (Shorea pinanga) jenis-jenis ini termasuk dalam daftar merah IUCN yaitu sebagai jenis Critially Endangered (Heriyanto dan Subiandono 2003).

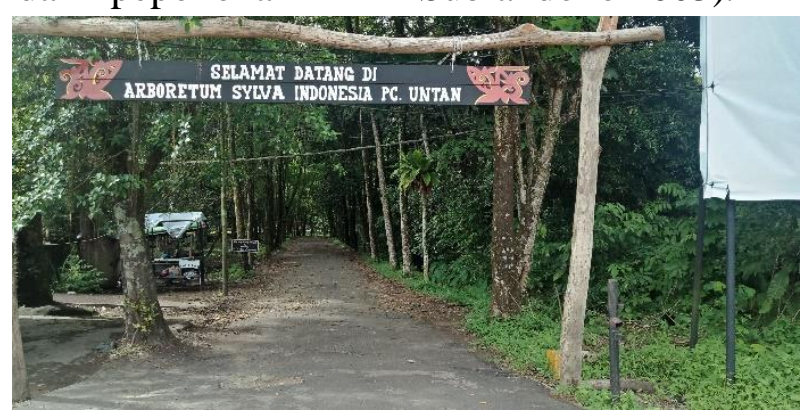

Gambar 1. Arobretum Sylva Indonesia PC UNTAN

Sejalan dengan fungsi dari Hutan Kota, jenis pohon yang dimiliki Arboretum Sylva Indonesia PC UNTAN terdiri dari jenis yang dapat memperbaiki dan menjaga iklim mikro dan nilai estetika, dapat meresap air, menciptakan keseimbangan lingkungan fisik kota dan mendukung pelestarian keanekaragaman hayati.

Arboretum Sylva Indonesia PC UNTAN berada di tengah kota Pontianak dan telah dianggap sebagai penyumbang oksigen, penyerap polutan yang sumber utama nya dari kendaraan sehingga apabila berada di dalam nya 
merasakan udara yang segar di tengah padatnya kota Pontianak. Guna memaksimalkan fungsi dari tipe hutan kota yang ada di Arboretum Sylva Indonesia PC UNTAN dengan meningkatkan status kawasan menjadi Hutan Kota akan memberikan penjamin kelestarian yang telah ada dan menjaga lingkungan kota Pontianak tetap asri.

\section{Pendopo Gubernur Kalimantan Barat}

Berdasarkan hasil identifikasi tipe hutan kota di lokasi penelitian yang kedua, Pendopo Gubernur KALBAR memiliki tipe rekreasi. Tipe rekreasi pada Hutan Kota Pendopo dimaksud sebagai kebutuhan rekreasi dan keindahan, dengan jenis perpohonan yang indah dan unik. Hutan Kota Pendopo Gubernur dimaksud sebagai salah satu Ruang Terbuka Hijau dan sebagai tempat edukasi untuk anakanak, tempat wisata bagi masyarakat serta sebagai replika hutan hujan tropis yang mana didalamnya terdapat satwasatwa (Gambar 2). Namun, dapat dilihat pada Gambar 2 terhadap kondisi fisik Pendopo Gubernur KALBAR, terdapat sejumlah pendopo, alat bermain yang terlihat tidak layak dan media jalan sepetak yang dipenuhi oleh serasah sehingga Pendopo Gubernur kurang layak untuk dijadikan sebagai tempat berekreasi.

Berdasarkan hasil penelitian, jenis pohon penyusun Pendopo Gubernur KALBAR berisikan 21 jenis pohon. jenis pohon penyusun Pendopo Gubernur KALBAR tergolong dalam 12 famili yang di dominasi oleh famili Fabaceae (6 spesies), diikuti famili Euphorbaceae (2 spesies), dan famili Lythraceae, Myrataceae, Combretaceae, Euphorbaceae, Meliaceae, Apocynaceae, Eugenia, Phyllantaceae, Verbenaceae, Loganiaceae, Sapotaceae yang hanya terdapat 1 spesies.

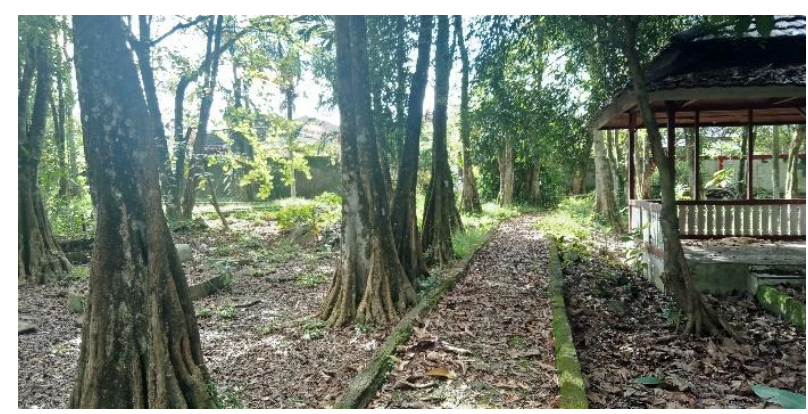

Gambar 2. Pendopo Gubernur Kalimantan Barat(West Borneo Guvernor's Pavilion)

Famili Fabaceae juga terdiri dari jenis fast growing yaitu Sengon (Falcataria molucana) dan jenis lainnya seperti Akasia daun kecil (Acacia mangium) Akasia daun lebar (Akasia auclariformis) yang juga dimiliki oleh jenis pohon penyusun Arboretum Sylva Indonesia PC UNTAN. Hal yang membedakan adalah jenis pohon dari famili Dipterocarpaceae tidak djjumpai dalam tingkatan pohon yang memiliki DBH $20 \mathrm{~cm}$ di Pendopo Gubernur KALBAR, sehingga dapat dinilai jenis yang ditanam tidak lah beragam dan hanya berisi jenis-jenis yang sering ditemukan pada jenis pohon yang ditanam pada pinggir jalan seperti Mahoni 


$\begin{array}{lrr}\text { (Swietenia } \quad \text { mahagoni), } & \text { Angsana } \\ \text { (Pterocarpus } \quad \text { indicus), } & \text { Sungkai } \\ \text { (Paronema canascens), } & \text { Tanjung } \\ \text { (Mimusop elengi). } & \\ & \end{array}$

Hutan kota Pendopo Gubernur Kalimantan Barat telah memberikan fungsi estetika berupa keberadaan hutan kota di tengah Pontianak Kota yang menyajikan keindahan tajuk, percabangan dan bunga. Sedangkan, Hutan Kota Pendopo Gubernur Kalbar belum maksimal dalam menyajikan fungsi hutan kota secara silvikultural. Dapat dilihat dari jenis pohon penyusunnya yang kurang beragam dan kurangnya jenis pohon endemik Kalimantan. Beberapa hal inilah yang menyebabkan diperlukannya unit pengelola manajemen dalam membangun Hutan Kota Pendopo Gubernur Kalbar untuk meningkatkan fungsi hutan kota secara maksimal.

\section{Kesesuaian Jenis Pohon Penyusun Hutan Kota}

Evaluasi kesesuaian jenis pohon penyusun hutan kota sangat diperlukan dalam pemantauan fungsi hutan kota. Hasil evaluasi ini juga dapat dipergunakan sebagai dasar pertimbangan dalam penataan jenis pohon hutan kota maupun rencana pembangunan hutan kota di suatu daerah. Evaluasi kesesuaian jenis pohon penyusun hutan kota pada penlitian ini dilakukan dengan cara menentukan skor setiap jenis pohon berdasarkan pada persyaratan silvikultural, manajemen dan estetika pohon pada lokasi penelitian.

Terdapat total 41 jenis pohon penyusun di Arboretum Sylva Indonesia PC UNTAN dan Pendopo Gubernur
Kalimantan Baratyang memiliki kriteria sesuai berdasarkan persyaratan silvikultural, manajemen dan estetika.

1. Arboretum Sylva Indonesia PC UNTAN

Terdapat total 38 jenis pohon yang terdiri dari 35 jenis pohon yang masuk kedalam kategori Sesuai (S) dan 3 jenis lainnya masuk dalam kategori Cukup Sesuai (CS). Jenis pohon yang masuk kedalam kategori Cukup Sesuai (CS) diantaranya Akasia (Acacia mangium), (Acacia auricaliformis), Sungkai (Paronema canascens). Jenis pohon yang masuk kedalam kategori Sesuai (S) disajikan pada Tabel 5 .

\section{Pendopo Gubernur Kalimantan Barat}

Pendopo Gubernur terdiri dari 18 jenis masuk kedalam krtieria Sesuai (S) dan 3 jenis lainnya masuk kedalam kategori Cukup Sesuai (CS). Jenis pohon yang masuk kedalam kategori Cukup Sesuai (CS) diantaranya Akasia (Acacia mangium), (Acacia auricaliformis), Sungkai ( Paronema canascens). Tabel 4 disajikan data rinci mengenai jenis pohon penyusun hutan kota pada lokasi penelitian dan kriteria kesesuaiannnya.

Jenis pohon penyusun huta kota diarahkan pada jenis pohon yang sesuai dengan tempat tumbuh serta efektif dalam pengendalian pencemaran udara atau memiliki daya tahan yang tinggi terhadap paparan polutan. Jenis pohon penyusun hutan kota berdasarkan potensi pohon dalam pengendalian pencemaran udara di perkotaan juga penting untuk persayaratan silvikultural, manajemen dan estetika. 
Tabel 4. Jenis pohon penyusun hutan kota dan kriteria kesesuaian (Urban Forest trees species and suitability criteria)

\begin{tabular}{|c|c|c|c|c|c|c|c|}
\hline No & Nama Botani & Nama Lokal & Famili & & & Skor & Ket \\
\hline & & & & 1 & 2 & & \\
\hline 1 & 2 & 3 & 4 & 5 & 6 & 7 & 8 \\
\hline 1 & Acacia auricaliformis & Akasia daun kecil & Fabaceae & + & + & 38 & CS \\
\hline 2 & Acacia mangium & Aksasia daun lebar & Fabaceae & + & + & 38 & CS \\
\hline 3 & Pterocarpus indicus & Angsana & Fabaceae & + & + & 42 & $\mathrm{~S}$ \\
\hline 4 & Shorea laevis & Bengkirai & Dipterocarpaceae & + & & 41 & $\mathrm{~S}$ \\
\hline 5 & Calophyllum $s p$ & Bintangor & Clusiaceae & + & & 42 & $\mathrm{~S}$ \\
\hline 6 & Lagerstroemia speciosa & Bungur & Lythraceae & + & + & 43 & $\mathrm{~S}$ \\
\hline 7 & Artocarpus integer & Cempedak & Moraceae & + & & 42 & $\mathrm{~S}$ \\
\hline 8 & Aquilaria mallaccensis & Gaharu & Thymelaeaceae & + & & 40 & $S$ \\
\hline 9 & Syzygium aqueum & Jambu air & Myrataceae & + & + & 43 & $\mathrm{~S}$ \\
\hline 10 & Melicope lunu-akenda & Jampang & Rutaceae & + & & 43 & $\mathrm{~S}$ \\
\hline 11 & Gmelina arborea & Jati Putih & Verbenaceae & + & & 42 & $\mathrm{~S}$ \\
\hline 12 & Dyera costulata & Jelutung & Apocynaceae & + & & 42 & $S$ \\
\hline 13 & Senna slamea & Johar & Fabaceae & + & & 43 & $\mathrm{~S}$ \\
\hline 14 & Shorea balangeran & Kawi & Dipterocarpaceae & + & & 41 & $\mathrm{~S}$ \\
\hline 15 & Picus sp & Beringin & Moraceae & + & & 41 & $S$ \\
\hline 16 & Terminalia catapa & Ketapang & Combretaceae & + & + & 44 & $\mathrm{~S}$ \\
\hline 17 & Vitex pinnata & Leban & Lamiaceae & + & & 41 & $S$ \\
\hline 18 & Macaranga triloba & Mahang & Euphorbiaceae & + & + & 42 & $S$ \\
\hline 19 & Macaranga denticulata & Mahang & Euphorbiaceae & + & + & 42 & $S$ \\
\hline 20 & Shorea palembanica & Meranti & Dipterocarpaceae & + & & 41 & $S$ \\
\hline 21 & Shorea parvistipulata & Meranti & Dipterocarpaceae & + & & 41 & $S$ \\
\hline 22 & Shorea stenoptera & Meranti & Dipterocarpaceae & + & & 41 & $S$ \\
\hline 23 & Shorea leprosula & Meranti & Dipterocarpaceae & + & & 41 & $S$ \\
\hline 24 & Shorea fallax & Meranti & Dipterocarpaceae & + & & 41 & $S$ \\
\hline 25 & Shorea pinanga & Meranti & Dipterocarpaceae & + & & 41 & $S$ \\
\hline 26 & Swietenia mahagoni & Mahoni & Meliaceae & + & + & 42 & $S$ \\
\hline 27 & Artocarpus sp & Peluntan & Moraceae & + & & 40 & $S$ \\
\hline 28 & Parkia speciosa & Petai & Fabaceae & & + & 41 & $S$ \\
\hline 29 & Syzygium oleana & Pucuk merah & Myrataceae & + & & 44 & $S$ \\
\hline 30 & Alstonia scholaris & Pulai & Apocynaceae & + & + & 41 & $\mathrm{~S}$ \\
\hline 31 & Eugenia plyantha & Salam & Eugenia & & + & 40 & $\mathrm{~S}$ \\
\hline 32 & Baccaurea motleyana & Rambai & Phyllantaceae & + & + & 40 & $\mathrm{~S}$ \\
\hline 33 & Vatica pauciflora & Resak & Dipterocarpaceae & + & & 43 & $\mathrm{~S}$ \\
\hline 34 & Adenanthera pavonina & Saga & Fabaceae & + & + & 44 & $\mathrm{~S}$ \\
\hline 35 & Falcataria molucana & Sengon & Fabaceae & + & + & 39 & $\mathrm{~S}$ \\
\hline 36 & Dillenia excelsa & Simpur & Dilleniaceae & + & & 39 & $\mathrm{~S}$ \\
\hline 37 & Paronema canescens & Sungkai & Verbenaceae & + & + & 38 & CS \\
\hline 38 & Fragrea fragrans & Tembesu & Loganiaceae & + & + & 43 & $\mathrm{~S}$ \\
\hline 39 & Shorea & Tengkawang & Dipterocarpaceae & + & & 40 & $\mathrm{~S}$ \\
\hline 40 & Eugenia $s p$ & Ubah & Eugenia & & + & 44 & $\mathrm{~S}$ \\
\hline 41 & Mimusop elengi & Tanjung & Sapotaceae & + & + & 44 & $\mathrm{~S}$ \\
\hline
\end{tabular}

Keterangan :

S : Sesuai ( Skor 38,33-46)

CS : Cukup Sesuai (Skor $>30,33-38,33$ )

$+\quad$ : Jenis pohon yang berada di lokasi 1 atau lokasi 2 
Dahlan, et al. (1989) menyatakan jenis pohon yang menyerap dan menjerap timbal $(\mathrm{Pb})$ sangat tinggi diantaraya Jambu biji (Psidium guajava), Ketapang (Terminalia catappa L.) dan Bungur (Lagerstroemia speciose). Sementara jenis pohon yang termasuk dalam menyerap dan menjerap timbal dengan kemampuan tinggi yaitu Mahoni (Swietenia mahagoni), jenis pohon dengan kemampuan sedang adalah manga (Mangifera indica), cemara gunung (Casuarina junghuhniana) dan Angasana (Perocarpus indicus Willd). Sedangkan dengan kemampuan rendah adalah kupu-kupu (Bauhnina purpurea), dan kenanga (Canarium odoratum). Kemampuan sangat rendah adalah Kiara payung (Filicium decipiens), kenari (Canarium commune), fikus (Fikus hirta), dadap (Erythrina variegate), dan akasia (Acacica auricaliformis).

Siringoringo (2000), jenis pohon yang memiliki kemampuan menyerap dan menjerap timbal (dengan kemampuan tinggi adalah johar (Cassia multijuga), sementara dengan kemampuan sedang adalah akasia (Acacia auricaliformis), sedangkan yang memiliki kemampuan rendah yaitu akasia (Acacia mangium) dan kupukupu (Bauhinia purpurea)

Jenis tanaman yang memiliki daya serap terhadap karbondioksida yang sangat tinggi $\left(\mathrm{CO}_{2}\right)$ menurut Dahlan (2008) adalah beringin (Ficus benjamina), kopal (Trachylobium verrucossum), pingku (Dysoxylum excelsum), kenanga (Canangium odoratum). Jenis pohon yang berdaya serap tiggi adalah bungur (Lagerstoemia speciosa), segawe (Adenanthera pavonina), selasihan (Cinnamomum parthenoxylon), mahoni (Switenia mahagoni), matoa (Pometia pinnata), Kiara paying (Filicium decipiens), medang (Beilschmedia roxburghiana). Jenid berdaya serap sedang adalah puspa (Schima wallichii), sirsak (Annona muricata), khaya (Khaya senegalensis), mahoni (Swietenia mahagoni), johar (Cassia grandis), nangka (Artocarpus heterophyllus), jati (Tectona grandis). Sedangkan jenis pohon dengan berdaya serap rendah adalah angsana (Pterocarpus indicus), pacira (Pachora affinis), akasia (akasia mangium), maya-maya (Sapium indicum), merbau (Instia bijuga), mahoni afrika (Khaya anthotheca), pelahlar (Dipterocarpus retusa), kembang merak (Caesalpinia pulcherrima), carapa (Carapa guinensis). Jenis dengan berdaya serap sangat rendah adalah kedundung (Koompasia excelsa), merawan ( Hopea odorata), dadap merah (Erythrina crista-galli), sapu tangan (Maniltoa grandflora), dan asem keranji (Pithecelobium dulce).

Kusminingrum (2008) menyatakan jenis pohon yang efektif menyerap karbon monoksia (CO) madalah genitri (Elaeocarpus sphaericus), bungur (Lagerstroemia flos-reginae), cempaka (Michelia champaca), bunga merak (Caesalpinia champaca), sapu tangan (Maniltoa grnadflora), kupu-kupu (Bauhiniapurpurea), tanjung 
(Mimusops elengi), dan kecrutan (Spathodea campanulata).

Jenis pohon yang efektif dalam menyerap nitrogen dioksia dari udara menurut Sulistijorini (2009) adalah flamboyant (Delonix regia), tranjung
(Mimusops elengi), angsana (Pterocarpus indicus), kayu manis (Cinnamomum burmanii), mahoni (Swietenia mahagoni), bungur (Lagerstroemia speciosa), dan melina (Gmelina arborea).

Tabel 5. Jenis Pohon penyusun hutan kota yang efektif dalam pengendalian pencemaran udara (Urban forest trees species that are effective in controlling air pollution)

\begin{tabular}{|c|c|c|c|c|c|c|}
\hline \multirow{2}{*}{ No } & \multirow{2}{*}{ Nama Ilmiah } & \multirow{2}{*}{ Nama Jenis } & \multicolumn{4}{|c|}{ Penyerap } \\
\hline & & & $\mathrm{Pb}$ & $\mathrm{CO}_{2}$ & $\mathrm{CO}$ & $\mathrm{NO}_{2}$ \\
\hline 1 & 2 & 3 & 4 & 5 & 6 & 7 \\
\hline 1 & Acacia aucaliformis & Akasia & $\sqrt{ }$ & $\sqrt{ }$ & & $\sqrt{ }$ \\
\hline 2 & Acacia mangium & Akasia & $\sqrt{ }$ & $\sqrt{ }$ & & $\sqrt{ }$ \\
\hline 3 & Lagerstroemia speciosa & Bungur & $\sqrt{ }$ & $\sqrt{ }$ & $\sqrt{ }$ & $\sqrt{ }$ \\
\hline 4 & Mimusops elengi & Tanjung & $\sqrt{ }$ & & $\sqrt{ }$ & $\sqrt{ }$ \\
\hline 5 & Pterocarpus indicus & Angsana & $\sqrt{ }$ & $\sqrt{ }$ & & \\
\hline 6 & Swietenia mahagoni & Mahoni & $\sqrt{ }$ & $\sqrt{ }$ & & $\sqrt{ }$ \\
\hline 7 & Gmelina arborea & Melina & & & & $\sqrt{ }$ \\
\hline 8 & Terminalia catappa & Ketapang & $\sqrt{ }$ & & & \\
\hline 9 & Cassia grandis & Johar & & $\sqrt{ }$ & & \\
\hline 10 & Fikus sp & Kayu ara & $\sqrt{ }$ & & & \\
\hline
\end{tabular}

Berdasarkan hasil penelitian (Tabel 5) terdapat 10 jenis pohon penyusun hutan kota di Pontianak Kota sebagai jenis pohon yang efektif dalam pengendalian pencemaran udara. Beberapa jenis pohon penghasil buah yang dikonsumsi manusia seperti, Jambu (Psidium guajava), ketapang (Terminalia catappa) juga memiliki kemampuan yang efektif dalam pengendalian pencemaran udara, khususnya partikel timbal $(\mathrm{Pb})$ yang biasanya dihasilkan dari gas kendaraan bermotor. Buah yang dihasilkan dari pohon yang tercemar partikel timbal apabila dikonsumsi oleh manusia dapat menggangu kesehatab. Partikel timval yang masuk kedalam jaringan tanaman, termasuk dalam buah. Apabila buah tersebut dikonsumsi oleh manusia, maka cemaran timbal yang terdapat di dalam buah akan masuk ke dalam tubuh manusia dan mengganggu kesehatan. Oleh karena itu, jenis-jenis tersebut dapat dipilih sebagai jenis pohon penyusun hutan kota namun penempatannya akan lebih sesuai jika jauh dari sumber pencemar timbal.

\section{Posisi setiap jenis pohon penyusun hutan kota di Pontianak Kota}

Gambar 1 dan 2 menunjukkan posisi setiap individu jenis pohon di Arboretum Sylva Indonesia PC UNTAN dan Pendopo Gubernur Kalimantan Barat yang disimbolkan dengan nama pohon, kriteria kesesuaian dan diberi simbol titik dengan warna merah $(\bullet)$ yang artinya adalah dititik tersebut merupakan jenis pohon yang termasuk kedalam kriteria Sesuai (S), sedangkan symbol dengan warna $(\bullet)$ merupakan jenis pohon di setiap titik termasuk kedalam kriteria Cukup Sesuai. 
Vol. 7 (2) : 807 - 821

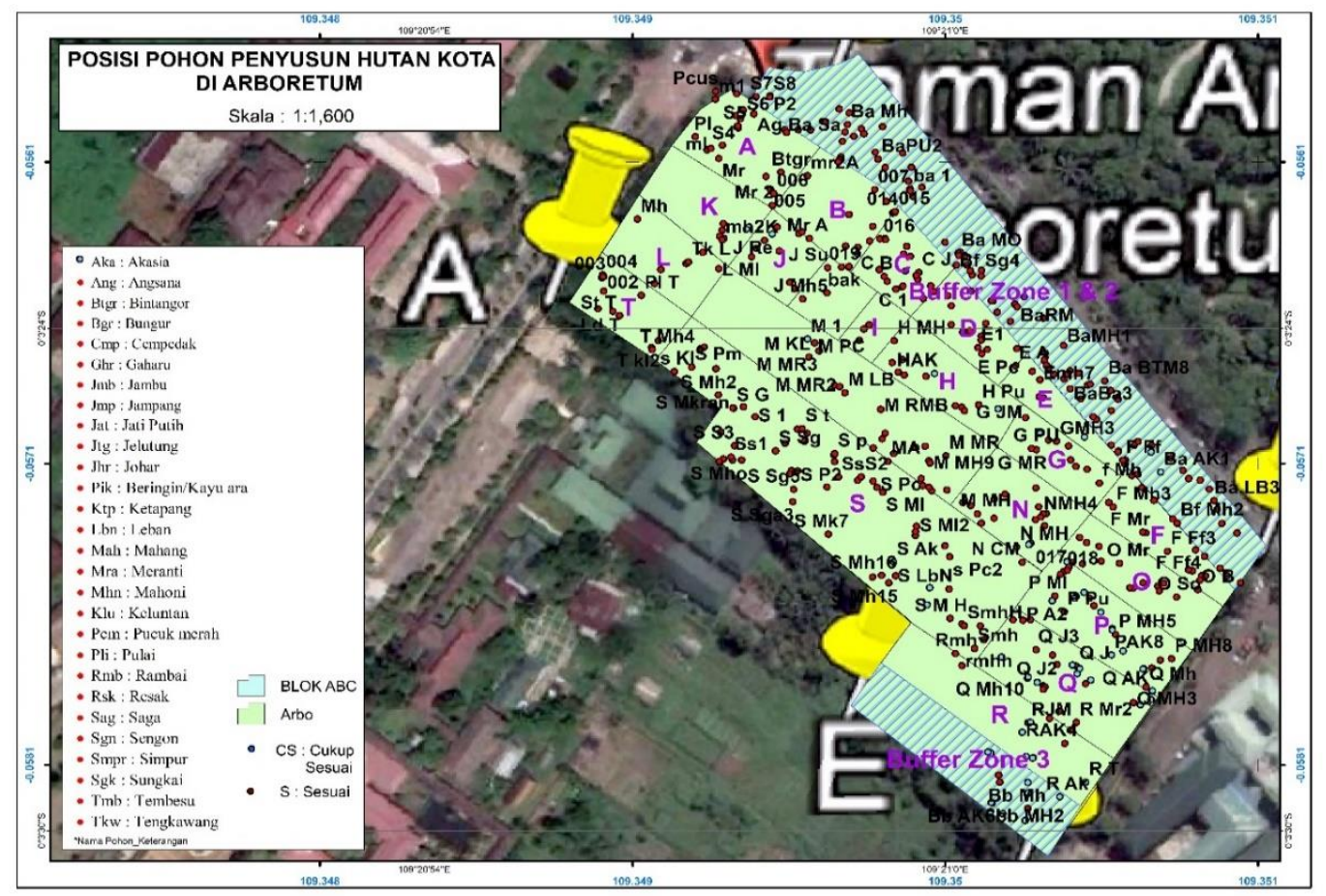

Gambar 1. Peta posisi pohon penyusun huta kota di Arboretum (The map position of trees compiler urban forst in Arboretum)

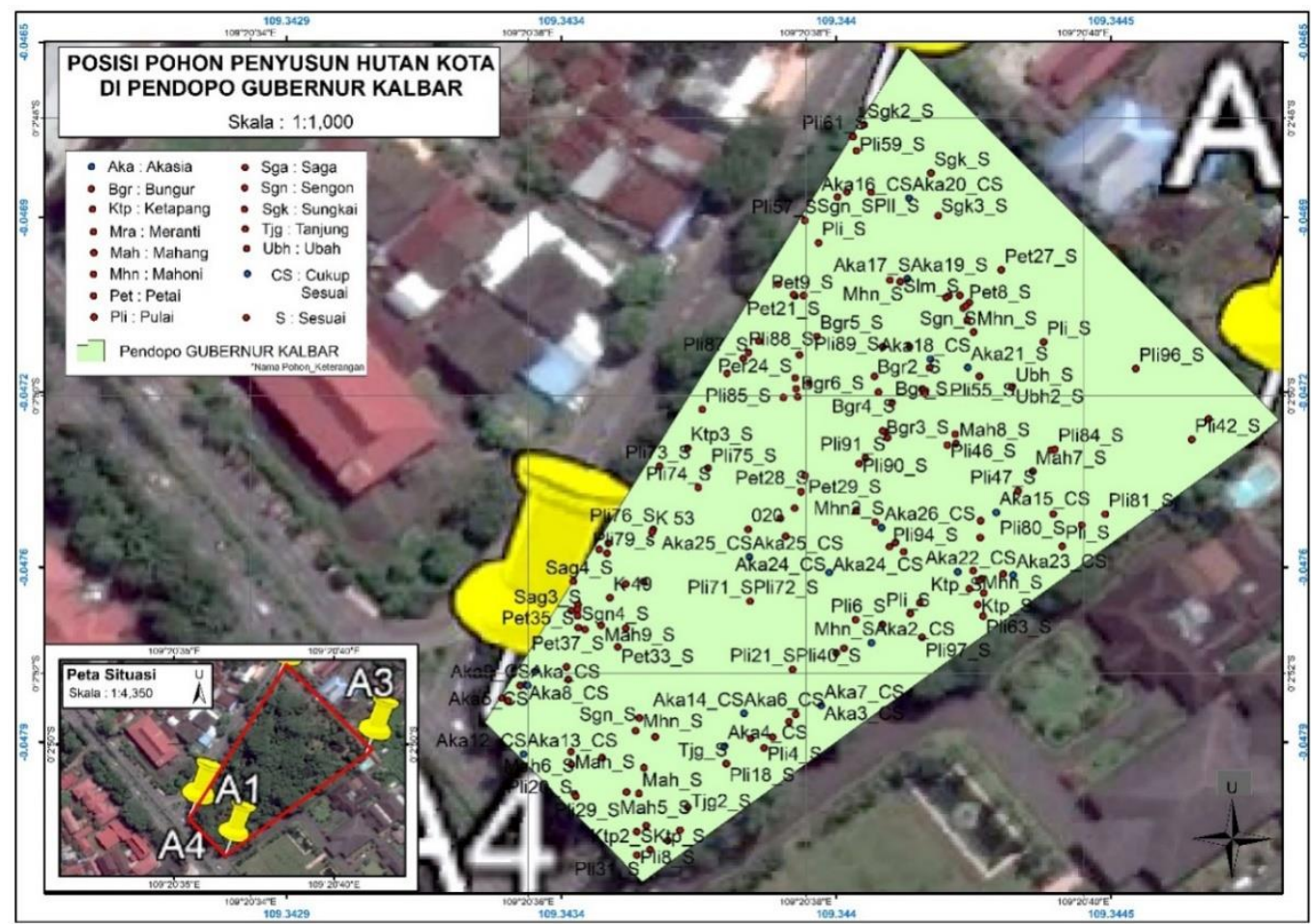

Gambar 2. Peta posisi pohon penyusun huta kota di Pendopo Gubernur Kalimantan Barat (The map position of trees compiler urban forest in West Borneo Guvernor's Pavilion)

Berdasarkan Tabel 6 jenis pohon di UNTAN yang memiliki kerapatan Arboretum Sylva Indonesia PC tinggi yaitu jenis Mahang (Macaranga 
triloba) 43,5 pohon/ha dengan jumlah individu sebanyak 145 pohon.

Tabel 6. Jumlah pohon dan kerapatan pohon di Arboretum Sylva Indonesia PC UNTAN(The amount of trees species and trees densitiy in Arboretum Sylva Indonesia PC UNTAN)

\begin{tabular}{|c|c|c|c|c|}
\hline No & Nama Pohon & Nama Latin & $\sum$ & $\mathrm{K}$ \\
\hline 1 & 2 & 3 & 4 & 5 \\
\hline 1 & Acacia auricaliformis & Akasia daun kecil & 20 & 6.25 \\
\hline 2 & Acacia mangium & Aksasia daun lebar & 24 & 7.5 \\
\hline 3 & Pterocarpus indicus & Angsana & 16 & 5 \\
\hline 4 & Shorea laevis & Bengkirai & 1 & 0.3125 \\
\hline 5 & Calophyllum $s p$ & Bintangor & 5 & 1.5625 \\
\hline 6 & Lagerstroemia speciosa & Bungur & 5 & 1.5625 \\
\hline 7 & Artocarpus integer & Cempedak & 3 & 0.9375 \\
\hline 8 & Aquilaria mallaccensis & Gaharu & 1 & 0.3125 \\
\hline 9 & Syzygium aqueum & Jambu air & 3 & 0.9375 \\
\hline 10 & Melicope lunu-akenda & Jampang & 20 & 6.25 \\
\hline 11 & Gmelina arborea & Jati Putih & 2 & 0.625 \\
\hline 12 & Dyera costulata & Jelutung & 3 & 0.9375 \\
\hline 13 & Senna slamea & Johar & 1 & 0.3125 \\
\hline 14 & Shorea balangeran & Kawi & 2 & 0.625 \\
\hline 15 & Fikus benjamina & Beringin & 10 & 3.125 \\
\hline 16 & Terminalia catapa & Ketapang & 2 & 0.625 \\
\hline 17 & Vitex pinnata & Leban & 7 & 2.1875 \\
\hline 18 & Macaranga triloba & Mahang & 145 & 45.3125 \\
\hline 19 & Macaranga denticulata & Mahang & 4 & 1.25 \\
\hline 20 & Shorea palembanica & Meranti & 12 & 3.75 \\
\hline 21 & Shorea parvistipulata & Meranti & 10 & 3.125 \\
\hline 22 & Shorea stenoptera & Meranti & 5 & 1.5625 \\
\hline 23 & Shorea leprosula & Meranti & 9 & 2.8125 \\
\hline 24 & Shorea fallax & Meranti & 5 & 1.5625 \\
\hline 25 & Shorea pinanga & Meranti & 5 & 1.5625 \\
\hline 26 & Swietenia mahagoni & Mahoni & 2 & 0.625 \\
\hline 27 & Artocarpus sp & Peluntan & 4 & 1.25 \\
\hline 28 & Syzygium oleana & Pucuk merah & 17 & 5.3125 \\
\hline 29 & Alstonia scholaris & Pulai & 10 & 3.125 \\
\hline 30 & Baccaurea motleyana & Rambai & 2 & 0.625 \\
\hline 31 & Vatica pauciflora & Resak & 1 & 0.3125 \\
\hline 32 & Adenanthera pavonina & Saga & 30 & 9.375 \\
\hline 33 & Falcataria molucana & Sengon & 5 & 1.5625 \\
\hline 34 & Dillenia excelsa & Simpur & 1 & 0.3125 \\
\hline 35 & Paronema canescens & Sungkai & 11 & 3.4375 \\
\hline 36 & Mimusop elengi & Tanjung & 5 & 1.5625 \\
\hline 37 & Fragrea fragrans & Tembesu & 6 & 1.875 \\
\hline \multirow[t]{2}{*}{38} & Shorea & Tengkawang & 4 & 1.25 \\
\hline & TOTAL & & 418 & \\
\hline
\end{tabular}

Berdasarkan Tabel 7 jenis pohon di Pendopo yang memiliki kerapatan tinggi yaitu jenis Pulai (Alstonia scholaris) 36 pohon/ha dengan jumlah 
individu sebanyak 83 pohon, paling terendah Salam (Eugenia plyantha), Angsana (Pterocarpus indicus), Jambu air (Syzygium aqueum), Rambai (Baccaurea motleyana), Tanjung
(Mimusop elengi), Tembesu (Fragrea fragrans), Ubah (Eugenia sp), Johar (Senna slamea) dengan nilai kerapatan 0,43 pohon/ha yang hanya memiliki satu individu.

Tabel 7. Jumlah pohon dan kerapatan pohon di Pendopo Gubernur Kalimantan Barat (The amount of trees species and trees densitiy in West Borneo Guvernor's Pavilion)

\begin{tabular}{|c|c|c|c|c|}
\hline No & Nama Latin & Nama lokal & $\sum$ & $\mathbf{K}$ \\
\hline 1 & 2 & $\mathbf{3}$ & 4 & 5 \\
\hline 1 & Acacia auricaliformis & Akasia daun kecil & 14 & 6.086957 \\
\hline 2 & Acacia mangium & Aksasia daun lebar & 4 & 1.73913 \\
\hline 3 & Pterocarpus indicus & Angsana & 1 & 0.434783 \\
\hline 4 & Lagerstroemia speciosa & Bungur & 6 & 2.608696 \\
\hline 5 & Fikus benjamina & Beringin & 2 & 0.869565 \\
\hline 6 & Syzygium aqueum & Jambu air & 1 & 0.434783 \\
\hline 7 & Senna slamea & Johar & 1 & 0.434783 \\
\hline 8 & Terminalia catapa & Ketapang & 3 & 1.304348 \\
\hline 9 & Macaranga triloba & Mahang & 5 & 2.173913 \\
\hline 10 & Macaranga denticulata & Mahang & 4 & 1.73913 \\
\hline 11 & Swietenia mahagoni & Mahoni & 5 & 2.173913 \\
\hline 12 & Parkia speciosa & Petai & 17 & 7.391304 \\
\hline 13 & Alstonia scholaris & Pulai & 83 & 36.08696 \\
\hline 14 & Eugenia plyantha & Salam & 1 & 0.434783 \\
\hline 15 & Baccaurea motleyana & Rambai & 1 & 0.434783 \\
\hline 16 & Adenanthera pavonina & Saga & 2 & 0.869565 \\
\hline 17 & Falcataria molucana & Sengon & 14 & 6.086957 \\
\hline 18 & Paronema canescens & Sungkai & 2 & 0.869565 \\
\hline 19 & Mimusop elengi & Tanjung & 1 & 0.434783 \\
\hline 20 & Fragrea fragrans & Tembesu & 1 & 0.434783 \\
\hline \multirow[t]{2}{*}{21} & Eugenia $s p$ & Ubah & 1 & 0.434783 \\
\hline & TOTAL & & 169 & \\
\hline
\end{tabular}

\section{KESIMPULAN}

1. Terdapat 41 jenis pohon penyusun hutan kota di Pontianak Kota. Hutan Kota Arboretum Sylva Indonesia PC UNTAN sebanyak 38 Hutan Kota Pendopo Gubernur Kalbar terdiri dari 21 jenis pohon.

2. Pada Aboretum Sylva Indonesia PC UNTAN jenis pohon yang termasuk ke dalam kategori Sesuai terdiri dari 35 jenis, 3 jenis diantaranya termasuk ke dalam kategori Cukup Seusai. Hutan
Kota Pendopo Gubernur Kalbar jenis pohon yang termasuk kedalam kategori Sesuai terdiri dari 18 jenis pohon, 3 diantarnya termasuk kedalam kategori Cukup Sesuai. Jenis pohon yang termasuk ke dalam kategori Cukup Sesuai (CS) terdiri dari Akasia daun kecil (Acacia auricaliformis), Akasia daun lebar (Acacia mangium) dan Sungkai (Paronema canascens).

3. Arboretum Sylva Indonesia PC UNTAN memiliki potensi sebagai 
hutan kota yang sudah maksimal dari segi persyaratan silvikultur, manajemen, dan estetika.

4. Pendopo Gubernur Kalimantan Barat memiliki potensi sebagai hutan kota yang kurang maksimal dari segi manajemen dan silvikultural namun sudah maksimal dalam segi estitika ditengah lingkungan kota.

\section{SARAN}

Arboretum Sylva Indonesia PC UNTAN dan Pendopo Gubernur Kalimantan Barat sebagai Hutan Kota di Kota Pontianak danguna memaksimalkan fungsi hutan kota, dibutuhkan unit manajemen yang dapat memaksimalkan upaya silvikultural pada Hutan Kota Pendopo Gubernur Kalimantan Barat.

\section{DAFTAR PUSTAKA}

BPS KALBAR. 2017. Kepadatan Penduduk 2000-2017. Badan Pusat Statistik Kalimantan Barat.

Indriyanto. 2006. Identifikasi dan Kesesuaian Spesies Vegetasi Penghijauan di Kota Bandar Lampung. ProsidisingSeminar Hasil-hasilPenelitian dan Pengabdian kepada Masyarakat,Buku I. Lembaga Penelitian UniversitasLampung. Bandar Lampung.Buku I. Lembaga Penelitian UniversitasLampung. Bandar Lampung.

Mukhlison. 2013. Pemilihan Jenis Pohon Untuk Pengembangan Hutan Kota Di Kawasan Perkotaan Yogyakarta.Jurnal Ilmu Kehutanan : Volume VII No. 1-Januari-Maret 2013.

Saebo A, Borzan Z, Ducatillion C, Hatzistathis A,Kagerstrom T, Supuka J, Garcia-Valdecantos
JL,Rego F, \& Slycken JV. 2005. The selection of plant material for street trees, park trees and urban woodland. Springer-Verlag BerlingHeidelberg.

Heriyanto N.M dan Subiandono E. 2003. Status Kelangkaan Jenis Pohon di Kelompok Hutan Sungai LekawaiSungai Jengonoi, Sintang, Kalimantan Barat. Puslitbang Hutan dan Konservasi. Badan Plasma Nutfah: Vol.9 No. 2. Bogor.

Dahlan EN, Ontaryo Y, dan Umasda. 1989. Kandungan Timbal pada Beberapa Jenis Pohon Pinggir Jalan di Jalan Sudirman, Bogor. JurnalMedia Konservasi2 (4) : 4550

Dahlan EN. 2008. Jumlah Emisi Gas $\mathrm{CO}_{2}$ dan Pemilihan Jenis Tanaman Berdaya Rosot Sangat Tinggi : Studi Kasus di Kota Bogor. Jurnal Media Konservasi13 (2) : 85-89

Kusminingrum N. 2008. Potensi Tanaman dalam Menyerap $\mathrm{CO}_{2}$ dan $\mathrm{CO}$ untuk Mengurangi Dampak Pemanasan Global. JurnalPemukiman 3 (2) : 96-105

Siringoringo HH. 2000. Kemampuan Beberapa Jenis Tanaman Hutan Kota dalam Menjerap Partikulat Timbal. Buletin Penelitian Hutan $622: 1-16$

Sulistijorini. 2009. Keefektian dan Toleransi Jenis Tanaman Jalur Hijau Jalan dalam Mereduksi Pencemar $\mathrm{NO}_{2}$ Akibat Aktivitas Transportasi, Pascaserjana Institut Pertanian. Bogor 